\title{
Thomas Browne and the Silent Text
}

\author{
JESSICA WOLFE \\ University of North Carolina at Chapel Hill
}

\begin{abstract}
Throughout his writings, the physician and essayist Thomas Browne (1605-82) grapples with the problem of how and whether to interpret the silence of texts. His innovative solutions to the problem of "negative authority," the term used in early modern theological debates over the significance, or lack thereof, vested in things omitted by the scriptures, challenge more conventional reformed defenses of scriptural perspicuity and also reveal how these hermeneutic puzzles in turn shape Browne's understanding of the relationship between theology and natural philosophy and between rhetoric and logic. This article analyzes Browne's idiosyncratic treatment of textual silence within its historical moment and also considers the interpretive challenges posed by omissions in Browne's own writings, focusing in particular on his Pseudodoxia Epidemica.
\end{abstract}

À travers son ceuvre, le médecin et essayiste Thomas Browne (1605-82) se demande s'il faut interpréter le silence des textes, et si oui, comment. À la question de "l'autorité négative ", ainsi que le problème était nommé dans les débats théologiques de la première modernité - que signifient les silences et les omissions des Écritures, s'ils signifient quelque chose? - il répond de manière originale et défie les défenses réformées, plus conventionnelles, de la perspicacité scripturale; ces réponses révèlent également l'influence de ces énigmes herméneutiques, en retour, sur la conception de Browne quant aux relations entre théologie et philosophie naturelle, ainsi qu' entre rhétorique et logique. Cet article analyse la façon spécifique dont Browne, dans son contexte historique, traite du silence textuel, et il considère les problèmes d'interprétation que posent les omissions dans les textes de Browne lui-même, en particulier dans son Pseudodoxia Epidemica.

(1646-72), Thomas Browne grapples with the problem of how and whether
(16ica to interpret the silence of texts. In a chapter of his encyclopedia of vulgar errors devoted to the question of "whether the world was slenderly peopled before the flood," Browne wrestles with the difficulty of taking a biblical census on the grounds that "in the relation of Moses there be very few persons mentioned, yet are there many more to be presumed," an interpretation principally indebted to Augustine. ${ }^{1}$ Augustine's City of God is one of several patristic texts that lays out a hermeneutic method for proceeding when the scriptures remain silent

1. Thomas Browne, Pseudodoxia Epidemica 6.6, ed. Robin Robbins, 2 vols. (Oxford: Clarendon Press, 1981), 1:471-72, hereafter cited parenthetically as $P E$, indicating book and chapter, and then page numbers in the Robbins $(R R)$ edition.

Renaissance and Reformation / Renaissance et Réforme 40.2, Spring / printemps 2017 
on a given detail, or when a passage supplies only a partial or implicit account that might be interpreted, as Augustine puts it, "a Synecdoche partis" or "pars pro toto" (taking the part for the whole). ${ }^{2}$ Browne's explication of antediluvian demography is punctuated throughout by concessions to the problem that the "brief narration" offered by Moses in chapters 4 through 6 of Genesis gives us "but slender information" about everything that may actually have transpired between the Fall and the Flood, a position that challenges more conventional reformed defenses of scriptural perspicuity, especially those articulated in contemporary debates over adiaphora, even as it also unravels a hermeneutic puzzle that occupies Browne in various ways throughout the 1640s and 1650s as he labours to establish to what extent and under what circumstances textual silences-wholesale omissions, incomplete passages, or things tacitly but not explicitly named in a text—can and should be filled in by readers. ${ }^{3}$

Omissions, synecdoches, and other instances of textual silence present various hermeneutic obstacles to Browne and provoke equally diverse solutions from him at a moment when biblical interpretation had become both fragmented and radically controversial. In Pseudodoxia alone, there are more than fifteen places where Browne either interprets, or notices and then resists interpreting, silences in scriptural or classical texts, a habit that reveals how, for Browne, "poor exegesis proves continually to lie at the root of error." ${ }^{4}$ These include the non-mention of minerals in the biblical account of creation; the question of whether Christ ever laughed, even if scripture nowhere records him doing so; whether the Bible's failure to mention wine before the Flood makes Noah the inventor of it; whether the Bible is in fact silent on where the ark rested at the conclusion of the Flood; Aristotle's non-mention of the basilisk; the failure of classical writers to mention clocks, even though they existed during antiquity; the array of common early modern purgatives, such as Senna and Rhubarb, nowhere mentioned by various Greek medical authorities; whether the "three

2. Augustine, Of the Citie of God 15.15 (London, 1610), 550-52; compare Citie of God 18.31, 718; De Doctrina Christiana 3.35.50, in Patrologia Latina 34, ed. J. P. Migne, col. 80.

3. On Browne's conception of adiaphora and its relevance to biblical exegesis, see Andrew Cunningham, "Sir Thomas Browne and his Religio Medici: Reason, Nature and Religion," in Religio Medici: Medicine and Religion in Seventeenth-Century England, ed. Ole Peter Grell and Andrew Cunningham (Aldershot: Scolar Press, 1996), 29.

4. Kevin Killeen, Biblical Scholarship, Science and Politics in Early Modern England: Thomas Browne and the Thorny Place of Knowledge (Farnham: Ashgate, 2009), 15. 
days" during which Jonas inhabited the belly of the whale implies that he spent three nights there, or only two; why the scripture repeatedly mentions the heart, but the "brain" only once (and only in the Vulgate at that). At times, Browne suspends judgment on the possible motives for a given omission; at other times, however, he offers surprisingly diverse reasons for why an author might overlook, or even intentionally neglect to mention, a detail that readers might expect or wish to find in a given text.

This article aims to illustrate the novelty of Browne's strategies for interpreting textual silence within his historical moment, analyzing his idiosyncratic approach to questions germane to all literary critics, especially those conscious of the methodological limitations of critique and of symptomatic of, what Eve Kosofsky Sedgwick has called paranoid, reading: namely, how to construe textual oversights, omissions, deficiencies, and evasions, and how to determine what a particular text is unable or unwilling to say. ${ }^{6}$ Browne's attention to this set of hermeneutic problems sheds light upon his understanding of the relationship between theology and natural philosophy, and between rhetoric and logic, and it also sheds light on Browne's own habits of omission and aposiopesis, habits with which I have grappled while annotating a new edition of Pseudodoxia. The very act of annotation requires discerning and then filling in omitted pieces of information that, once added, enhance or supplement the meaning of a text. But when the text in question is so alert to the silences and omissions of its sources, and so subtly mischievous in drawing the reader's attention to its own omissions, the annotator's task becomes thornier even as it also becomes possible to learn from Browne himself how to handle silences and lapses in his own texts.

5. See, respectively, Pseudodoxia Epidemica 2.1 (minerals); 7.16 .3 (Christ's laughter; the invention of wine; heart and brain); 6.6 (the location of the ark); 3.7 (the basilisk); 5.18 (clocks); 4.13 (purgatives); 6.1 (the duration of Jonah's time in the whale). In The Garden of Cyrus, in The Prose of Sir Thomas Browne, ed. Norman Endicott (New York: Anchor Books, 1967), 299-300, Browne discusses once again whether Noah was the first vintner.

6. On the limits of critique and the hermeneutics of suspicion, see Rita Felski, "Suspicious Minds," Poetics Today 32.2 (2011): 215-34; Bruno Latour, "Why Has Critique Run Out of Steam? From Matters of Fact to Matters of Concern," Critical Inquiry 30:2 (2004): 225-48; Robert Koch, “The Critical Gesture in Philosophy," Iconoclash: Beyond the Image Wars in Science, Religion, and Art, ed. Bruno Latour and Peter Weibel (Cambridge: MIT Press, 2002), 524-36. 
In classical and Renaissance literature, textual silences may be signs of linguistic failure or of eloquence, like the "speechless dialect" of Shakespeare's Isabella, of subtle protest or discretion, of an apophatic mysticism, like the silent hymns of Hermes Trismegistus, or of a sublime indignation, like Ajax's silence towards Odysseus in Hades. ${ }^{7}$ Yet the range of possible causes that Browne posits for textual silence in Pseudodoxia Epidemica often deviates from these more conventional examples. In a chapter on the beaver, Browne notes how curious it is that Plutarch nowhere mentions the animal's sagacity and especially "its artifice in building" in an essay devoted to cunning in the animal world, since this evidence would have "much advantaged the drift of that discourse" (PE 3.4; $R R$ 1:173). Discussing Galen's failure to mention certain extremely toxic substances, Browne reasons that the physician was reluctant to bequeath to his readers "too subtile a Theory of poysons; unarming thereby the malice of venemous spirits, whose ignorance must be contented with Sublimate and Arsenick" (PE 7.19; RR 1:608). ${ }^{8}$ The first omission seems an accidental and unfortunate oversight, while the second appears deliberate, and prudently so, since "in things of this nature, silence commendeth history: 'tis the veniable part of things lost; wherein there must never rise a Pancirollus, nor remain any Register but that of hell." Referring to Guido Pancirolli's Rerum Memorabilium (1599), an encyclopedia of ancient discoveries and inventions subsequently

7. On Hermes and Ajax, see Achille Bocchi, Symbolicarum Quaestionum (Bologna, 1574), 67; Homer, Odyssey 11.563-67 (LCL 105: 440). On textual silences in classical and Renaissance literature, see Silvia Montiglio, Silence in the Land of Logos (Princeton, NJ: Princeton University Press, 2010); Benjamin Eldon Stevens, Silence in Catullus (Madison: University of Wisconsin Press, 2013); Carla Mazzio, The Inarticulate Renaissance: Language Trouble in an Age of Eloquence (Philadelphia: University of Pennsylvania Press, 2009); William Franke, On What Cannot Be Said, 2 vols. (South Bend: Notre Dame University Press, 2007); Alwin Thaler, Shakespeare's Silences (Cambridge, MA: Harvard University Press, 1929); Philip C. McGuire, Speechless Dialect: Shakespeare's Open Silences (Berkeley: University of California Press, 1985); Adam Swann, “'Silence and Sufferance': the Tacit Milton," Renaissance Studies 25:2 (2011): 334-37; Noam Reisner, Milton and the Ineffable (Oxford: Oxford University Press, 2010); Kevin Curran, “Treasonous Silence: The Tragedy of Philotas and Legal Epistemology, English Literary Renaissance 42:1 (2012): 58-89; Christopher J. Kendrick, Omissions Are Not Accidents: Modern Apophaticism from Henry James to Jacques Derrida (Toronto: University of Toronto Press, 2010).

8. Similar arguments are routinely made about Scripture omitting the worst sins and errors: see William Harrison, The Description of England (London, 1577), f. 97r on how the "prophet shutteth up in silence" the worst sins committed in Sodom and Gomorrah. 
forgotten or misplaced in the shuffle of history, Browne meditates on Galen's omission as a gift to posterity, a salutary lacuna best left empty.

More frequently, however, Browne interprets textual omission as evidence of an author's skeptical reluctance to adjudicate a thorny or insoluble conflict. Addressing the myth that the chameleon lives only on air, he notes that Aristotle "hath made no mention of this remarkeable propriety; which either suspecting its verity, or presuming its falsity hee surely omitted; for that he remained ignorant of this account it is not easily conceivable, it being the common opinion, and generally received by all men" (PE 3.21; $R R$ 1:242). Once again, in a chapter investigating whether the ostrich is able to digest iron, Browne lists a number of ancient authorities who partially or wholly neglect to endorse the legend, again interpreting their silence as doubt or disbelief: Aristotle and Oppian are "silent in this singularity, either omitting it as dubious, or [...] rejecting it as fabulous," while Pliny merely affirms that ostriches have excellent digestion, and Aelian "delivereth, that it digesteth stones, without any mention of Iron" (PE 3.22; $R R$ 1:252). In his rather vicious animadversions on the last of these passages, Alexander Ross baulks at Browne's willingness to interpret the reticence of these natural philosophers as evidence of anything at all: their silence, Ross counters, is "of no force, for arguments taken from a negative authority, were never held of any validity. Many things are omitted by them, which yet are true."

Ross assumes a position that, at least as far as the Bible was concerned, was commonplace in the 1630s and 1640s, thanks to strong arguments by the church fathers. In a 1631 work, Pierre Du Moulin offers up a lengthy catalogue of patristic authorities who maintain that it was "rash [...] to affirme anything, wherein the sacred Scripture is silent." ${ }^{10}$ Saint Ambrose offers the best known of these testimonies, warning against the danger of venturing any interpretation whatsoever of scriptural omissions and absences: "Who dare speak," Ambrose writes, "when the Scriptures are silent," the very formula challenged by Browne's assertion in Religio Medici (1643) that "where the Scripture is silent, the Church is my Text; where that speakes, 'tis but my Comment; where there is a joynt silence of both, I borrow not the rules of my Religion from Rome or Geneva, but 
the dictates of my owne reason." ${ }^{11}$ Despite the fact that Religio Medici models a hierarchical system that establishes the authority of the scriptures as superior to both the individual conscience and the community, Browne's claim that both ecclesiastical tradition and right reason may gloss, or fill in, scriptural gaps is unconventional, particularly when viewed from the vantage of Pseudodoxia, a text that strays from conventional approaches to the problem of "negative authority" - the hermeneutic significance, or lack thereof, vested in omissions and silences-both by translating a problem of biblical hermeneutics into the sphere of humane authors and by positing various interpretations of textual silence that complicate, if not totally upend, standard methods of dealing with negative authority.

In Religio, as well as in later works such as Pseudodoxia, Browne's position diverges from the Latin patristic tradition of Ambrose and Tertullian, the latter of whom maintains that "Scripture negates [or prohibits] what it does not mention" ("Negat Scriptura, quod non notat") and thus upholds the related argument, made by Eusebius among others, that there exist no biblical offspring except those explicitly mentioned in scripture. ${ }^{12}$ Browne flatly contradicts both these claims in Pseudodoxia, arguing that, when Cain slew Abel, "it doth not imply" that he killed one of only four people living at the time, since while the "line of Seth nominates but ten persons" in Genesis, it does not necessarily follow that "they [are] to be conceaved all that were of this generation" ( $P E$ 6.6; $R R$ 1:471-72). This discussion of extra, unnamed biblical persons in Pseudodoxia puts to rest the rather disturbing question of how Adam and Eve's abundant descendants, listed at Genesis 4.25-26, were all spawned from a sole surviving son. Yet Browne's assertion that there lived additional children unmentioned by Genesis, and yet present as actors in biblical history, also

11. On this oft-cited quotation, attributed to Ambrose during the Renaissance, see [Auctor incertus], De Vocatione Gentium 2.3 ('cujus erit tanta praesumptio, qui haec disserendo, existimet aperienda potius quam silentio miranda?'), in PL 17, ed. Migne, col. 1110D; English version cited from John Prideaux, "Idolatrous Feasting," in Certaine Sermons (London, 1636), 18; compare Hugo Grotius, Truth of the Christian Religion 7.19. Thomas Browne, Religio Medici 1.5, in Prose, ed. Endicott, 10, hereafter cited parenthetically in the text as RM. For a catalogue of how various church fathers weigh in on the issue, see Du Moulin, A Learned Treatise, 327-33; for a sympathetic reading of this passage in Religio, see Jonathan F. S. Post, Thomas Browne (Boston: Twayne, 1987), 40-41.

12. Tertullian, De Monogamia 4, in PL 2:934C, ed. Migne, and also cited by Richard Hooker, Of the Laws of Ecclesiastical Polity 2.5.2, in Works, 7 vols., ed. W. Speed Hill (Cambridge, MA and London: Folger Shakespeare Library, 1977-98), 1:161. 
challenges his earlier position, voiced at Religio Medici 1.21, which cautions against the investigation of questions not explicitly addressed in the scriptures: where Lazarus's soul idles while it awaits resurrection, for instance, or what season it was when the creation took place, the latter question dismissed in Religio as a "fantastick Quere" and yet treated at length (over two chapters) in book 6 of Pseudodoxia. ${ }^{13}$ Although Browne is dismissive of attempts to resolve this "catalogue of doubts" in Religio, Pseudodoxia treats these very same questions with an earnest, scholarly precision a decade later. Why does Browne change his mind about the kinds of questions that may and may not legitimately be asked about topics omitted by the Bible? Why do textual silences, both in the scriptures and outside of them, become so eminently interpretable for Browne despite the loud chorus of patristic and early modern warnings against speaking on behalf of a silent text?

There are several answers to this question, the first and most obvious one rooted in English theological debates of the 1630s and 1640s concerning adiaphora and scriptural perspicuity. The Church of England inherited from sixteenth-century Continental reformers, as well as from the patristic tradition before them, a messy variety of answers to the question of how and when, if ever, to place interpretive weight on the negative authority of the scriptures. Although Martin Luther initially endorsed the strict literalism of Tertullian, maintaining that, "whatever is without the word of God is, by that very fact, against God" ("eo ipso contra Deum, quod sine verbo Dei"), he gradually modifies this view, conceding that "nothing is to be settled beyond the scriptures, or if it is to be established, that it is to be counted free and not necessary" ("extra scripturas nihil esse statuendum, aut, sit statuitur, librum et non necessarium habendum"), a formula that continued to shape discussions of adiaphora down through the 1630s. By the end of his life, Luther had made a complete volteface from his initial position, declaring, "What is not against Scripture is for Scripture, and Scripture for it": in other words, whatever goes unmentioned in the Bible is not prohibited but rather tacitly approved by it. ${ }^{14}$

13. On the way in which Browne takes up these and other "pulsing questions" explored by Hugh Robinson, Browne's headmaster at Winchester, see Reid Barbour, Sir Thomas Browne: A Life (Oxford: Oxford University Press, 2013), 52-53.

14. Albert Henry Newman, A Manual of Church History, 2 vols. (Philadelphia: American Baptist Publishing Company, 1902), 2:308; see also Martin Luther, Letters 1, in Works, ed. Jaroslav Pelikan 
At stake in Luther's evolving view of scriptural silence is the belief that the Bible resorts frequently to synecdoche, a figure invoked by Augustine, John Cassianus, and other early theologians as a means of glossing what is left unsaid but also of explicating key theological concepts such as Christ's Hypostatic Union and the Eucharist, the latter of which Luther interprets synecdochally, rather than metonymically, in his debates with Zwingli and Oecolampadius in order to posit a theory of the Real Presence that explains the relationship of Christ's body to bread, not as a symbol or comparison but rather as a function of the pars pro toto relation between contained and container. ${ }^{15}$

Quite a few seventeenth-century English theologians, including Thomas Wilson and William Ames, employ similar hermeneutic methods to explain how the reference to "morning" at Genesis 1.5 in fact denotes a "whole Artificiall day" and how the "bread" in the Eucharist "is not onely like the body of Christ" but rather "made an adjunct of it" through a "Synecdoche of the part for the whole." ${ }^{16}$ Luther's final analysis of scriptural silence was not universally satisfactory to English reformers, however. Bishop John Jewel invoked a legal principle, "He that presents a mute body presents no body" ("Qui mutum exhibet nihil exhibet"), to protest against defenders of the Mass who relied upon a silent witness to testify on behalf of a ceremony nowhere explicitly represented in the scriptures. ${ }^{17}$ Jewel's position, like Luther's early insistence

(Saint Louis: Concordia Publishing House, 1963), 371; Henry Clay Vedder, The Reformation in Germany (New York: Macmillan, 1914), 305.

15. Martin Luther, Werke: kritische Gesammtausgabe (Weimar: H. Böhlau, 1883-2009) 121 volumes total [WA], 18:186-87; 26:443-45; on the importance of synecdoche to Luther's position on the Eucharist, see Richard Strier, "Martin Luther and the Real Presence in Nature," JMEMS 37.2 (2007): 271-303, 288; Christina Wald, The Reformation of Romance (Berlin: De Gruyter, 2014), 66; John Cassianus, De Incarnatione Christi Contra Nestorium Haereticum 6.23, in PL 50, ed. Migne, cols. 188B-189A: "in mentioning the Son of God you mention the Son of Man, and in mentioning the Son of Man you mention the Son of God: By the grammatical trope synecdoche in which you understand the whole from the parts, and a part is put for the whole." On the difference between metonymy and synecdoche, see also Jacobus Arminius, "On Sacraments in General," Disputation 60, in Works, 3 vols., trans. James Nichols (Auburn: Derby and Miller, 1853), 2:152.

16. Thomas Wilson, A Christian Dictionary (London, 1622), 310; 38; William Ames, The Sacred Marrow of Divinity 1.40.31 (London, 1642), 210.

17. John Jewel, A replie vnto $M$. Hardinges ansvveare by perusinge whereof the discrete, and diligent reader may easily see, the weake, and vnstable groundes of the Romaine religion (London, 1565), 77; the maxim is also quoted in Richard Smith, The prudentiall ballance of religion 1.13 (London, 1609), 124-25. 
that scriptural silence is prohibitive, was seen by some to be sanctioned by the scriptures themselves, in particular Deuteronomy 4.2, "Ye shall not add unto the word which I command you, neither shall ye diminish ought from it." 18 Yet so too was the contrary position, for a number of early modern commentators spied in the Bible numerous examples of rhetorical tropes such as reticentia, emphasis, repression, aposiopesis, or "mysterious reserve"-tropes of silence or omission that, according to rhetorical treatises of the period, leave "somewhat [...] left to be gathered" or "hol[d] backe of some thing that was to be spoken." ${ }^{19}$ This family of tropes has the effect of insinuating or leaving traces of what nonetheless remains unsaid: as Thomas Hobbes explains in his Art of Rhetoric, discussing various "figures of revocation, or calling back [...] [a] keeping of silence or Aposiopesis is, when the course of the sentence bygon is so stayed, as thereby some part of the sentence not being uttered, may be understood." 20

In the wake of the Admonition Controversy, Richard Hooker struck a typically moderate position on the issue, arguing that "in some cases a negative argument taken from scripture is strong," but in other cases less so, such that a cautious, faintly casuistical exercise of judgment is necessary lest one capitulate to one or the other of a dangerous pair of generalizations: that "all things are denied which scripture affirmeth not, or all things which scripture prescribeth not, condemned."21 In certain respects, Browne's declaration in Religio that both church and conscience may supply a legitimate "gloss" on scriptural silences shows the enduring influence of Hooker, particularly as reformulated by later writers such as Walter Raleigh, who grapples repeatedly with the problem of negative authority in his Historie of the World (1617) and concludes that

18. Deut. 4.2, as cited from The Bible: Authorized King James Version with Apocrypha, ed. Robert Carroll and Stephen Prickett (Oxford: Oxford University Press, 1997).

19. John Prideaux, Sacred Eloquence (London, 1659), 63; Lambert Daneau, A fruitfull commentarie vpon the twelue small prophets (London, 1594), n.p. On aposiopesis, see also John Smith, The mysterie of rhetorique unveil'd (London, 1665), 142-43.

20. Thomas Hobbes, Art of Rhetoric 7 (London, 1681), 154, providing the scriptural example from John 12.27, "So our Saviour Christ saith, My Soul is heavy: what shall I say?" Dudley Fenner cites the same verse as an example of aposiopesis in chapter 7 of his Art of Rhetorike (London, 1584).

21. Hooker, 2.5.2, in Works, 1:158; on Hooker's attitude toward the self-sufficiency of the scriptures, see Horton Davies, Worship and Theology in England, vols. 1 and 2 (Grand Rapids, MI: Eerdmans, 1996), $52-53$. 
"where the Scriptures are silent, the voyce of Reason hath the best hearing."22 Yet more so than any other seventeenth-century English writer I have found, Browne is, at least on occasion, willing to enlist the instrument of reason to make sense of what Pseudodoxia calls the "secret method of Scripture, which sometimes wholly omits, [and] seldome or never delivers the entire duration" of a given scriptural narrative ( $P E 7.3 ; R R$ 1:543). This is especially the case, Browne notes, when "wicked and faithlesse persons" are concerned, since evil figures are sometimes passed over by the Bible for reasons similar to those that prompt Galen, according to Browne, to omit the strongest poisons from his pharmacological writings.

Let us examine one especially provocative example of how Browne appears to understand this "secret method" at work. In book 7, chapter 16 of Pseudodoxia, Browne exposes the falsity of the common opinion that Christ never laughed, "because in Holy Scripture it is recorded he sometimes wept, but never that he laughed" (PE 7.16.3; $R R$ 1:588). Although Browne doesn't quibble with the assertion that the Bible nowhere represents the Savior laughing, he does protest that it is "hard to conceive how he passed his younger yeares and childhood without a smile," thus endowing Christ not just with a capacity for laughter but also with an entire childhood that, as was often noted by seventeenth-century biblical commentators, passes virtually unmentioned by the Gospels. Not only did Jesus have a childhood, according to Browne, he also had an utterly ordinary one: "he passed this age like other children," Browne writes, enjoying a normalcy that served two purposes: to give "assurance of his humanity unto men," and to conceal his "Divinity from the Divell" (PE 7.16.3). But before concluding his account, Browne exposes the "Alogie" or false logic of imagined opponents who might protest that it is "not reasonable to conclude from Scripture negatively in points which are not matters of faith," and he refutes these imagined adversaries by providing a long list of items not explicitly mentioned by the scriptures and yet also not prohibited or denied by them, for instance, that "there is no mention of fire" in the Creation," and yet "Christian philosophy did not thinke it reasonable presently to annihilate that Element, or positively to decree there was no such thing at all" (PE 7.16.3, RR 1:588-89). As Browne's first Miscellany Tract ("Observations upon Several Plants Mention'd in Scripture") likewise makes clear, with its long catalogue of plants and grains not mentioned in the 
scriptures, the Bible may appear encyclopedic, and yet it neglects to mention many natural objects and processes-the lodestone and magnet, oats and rice-that nonetheless were likely known to the ancient Hebrews regardless of whether the Bible saw fit to mention them. ${ }^{23}$ Like his adherence to a belief in guardian angels despite the fact that the creatures are "not manifestly defin'd in Scripture," Browne's other discussions of biblical omissions are concessions to the problem of accommodation, acknowledgements that the Bible is "at once divine and fictive," simultaneously encyclopedic and artfully abridged. ${ }^{24}$

Browne's insertion of a laughing childhood into the biblical account of Christ's life reflects his appreciation that textual omissions may result from a privileging of the extraordinary over the mundane. As he points out in the final chapter of Pseudodoxia, explaining why writers record some sins and not others, "[t]hey omit of monstrosity as they fall from their rarity" (PE 7.19; RR 1:608). While Christ's adulthood may have been singular and rare, his childhood, it seems, was ordinary - as ordinary as oats, a grain "so usefull" and "of ordinary use" in ancient times according to Browne, and yet never mentioned in the Bible nor discussed at any length by Theophrastus, "who is large about other Grains" (PE 7.19; MT 1.18; K 3:14). But Browne also offers an additional reason why the non-mention of Jesus's laughter in the New Testament does not necessitate concluding that the historical Jesus never laughed, and it has to do with genre: the "Scriptures [are] serious, and commonly omi[t] all Parergies," a neologism coined for the 1646 Pseudodoxia that means things which are beside the point (PE 7.16.3, $R R$ 1:589). The Bible is not, for Browne, a jestbook or comic drama: we should not therefore expect to find its characters laughing, and it would be "unreasonable from hence to condemne all laughter $[\ldots]$ for this is by a rusticall severity to banish all urbanity, whose harmlesse and confined condition as it stands commended by morality, so is it consistent with Religion, and doth not offend Divinity" (PE 7.16.3). The generic form and purpose of a text thus helps Browne to establish the validity or lack thereof of arguments made from negative authority, as is likewise revealed in Pseudodoxia's earlier discussion of Dioscorides's failure to mention unicorn's horn in his Materia

23. Thomas Browne, Observations upon Several Plants Mention'd in Scripture, Miscellany Tracts 1:46-49, in The Works of Sir Thomas Browne, ed. Geoffrey Keynes, 4 vols. (London: Faber \& Faber, 1928), 3:44-47. Henceforth referred to parenthetically as $M T$.

24. On Browne's belief in guardian angels and his conception of the scriptures as both divine and fictive, see Barbour, Sir Thomas Browne, 55 and 249. 
Medica. While the absence of Jesus's laughter is not a surprising omission, since the text in question does not concern laughing matters, Dioscorides's omission "affords some probability" that the ancient herbalist did not regard unicorn horn as medicinally effective, since his text intends "an accurate enumeration of Medicall materials" and yet leaves out this substance from its otherwise encyclopedic account of medicinal herbs and minerals (PE 1.7; $R R$ 1:43).

Arguments based on negative (or "silent") authority, then, vary in their legitimacy depending upon the perceived genre and intent of the text in question. When Ross takes exception to Browne's claim that the boy Jesus must have laughed despite the absence of scriptural evidence, he does so on the grounds that the scriptures speak not "superficially" but rather "exactly" about the life of Christ: "no lesse than four Evangelists write the story of Christ so fully," Ross argues, "that they mention all his passions and affections, as his anger, joy, sorrow, pity, hunger, thirst, feare, wearisomnesse" - but never his laughter. ${ }^{25}$ As Ross sees it, we may persuasively "reason from the negative" only when the scriptures treat a subject with thorough precision and nonetheless omit a detail, for when the Bible speaks superficially, "divers circumstances are omitted" and such lapses cannot reliably be interpreted as meaningful.

Yet for Browne, unlike Ross, the scriptures never attain the "strict and definitive expressions" required of philosophy. As Browne argues in the opening book of Pseudodoxia, the Bible "often omitteth the exact account of things, describing them rather to our apprehensions, then leaving doubts in vulgar minds, upon their unknowne and Philosophicall descriptions" (PE 1.9; $R R$ 1:54-55). This discursive and epistemological imparity between philosophy and theology helps to explain why Pseudodoxia begins, after its introductory book, with a consideration of two minerals - crystal and the magnet-that as Browne himself points out are never explicitly mentioned in the account of creation in Genesis. Although Pseudodoxia is widely and rightly understood to possess a hexameral structure, advancing over the course of six books from minerals to plants to human nature and supernature in imitation of the six days' creation, the work also aims to fill in scriptural gaps and omissions, so much so that in the opening chapter of book 2, devoted to crystal, Browne cautions, in a sentence added in 1658, that "we commonly consider subterranities not in contemplations sufficiently respective unto the creation," because "Moses 
$\mathrm{ha}[\mathrm{s}]$ left no mention of minerals, nor made any other description then sutes unto the apparent and visible creation" ( $P E$ 2.1; $R R$ 1:83). Browne's chapter on crystal is thus designed, in part, to fill in a scriptural absence that had proved especially vexing to commentators on Genesis from Augustine down to Benedictus Pererius and Fransiscus Vallesius, and to explain how, though the divine creation of minerals is nowhere explicitly described, the genesis of these substances is implicitly represented through God's generation of "seeds" or seminal principles that in turn suggests the formation of minerals in potentia if not in actuality. As Augustine explains, God creates certain creatures only as "causal reasons" or as "primordial causes [...] before they came forth in the visible shape proper to their kind." ${ }^{26}$ Pseudodoxia Epidemica begins its investigation into the Book of Nature with one such primordial cause, a substance named in Genesis only implicitly, and only as a silent seedling of its future self.

Books 2 and 6 of Pseudodoxia contain a number of chapters concerned with scientific subjects implicitly contained in the scriptures. Browne's approach to this problem in some respects echoes the method assumed by John Wilkins in his Discourse of a new planet (1640), which seeks to prove that there is a world in the moon despite the lack of scriptural evidence for such an argument. Wilkins adopts the commonplace position that "the negative authority of Scripture is not prevalent in those things which are not the fundamentals of Religion" in order to explain that Moses was not interested in discovering any "Mathematicall or Philosophicall subtilties" in Genesis, concluding that "the silence of Scripture concerning any other world, is not sufficient argument to prove that there is none." ${ }^{27}$ Yet while Wilkins insists upon the possibility of a world in the moon despite the Bible's failure to offer any evidence for it, thus valuing the freedom to posit truths unmentioned in the scriptures, Browne instead emphasizes the ways that scripture speaks to the very elements of creation about which it simultaneously remains silent, valuing the act of discovering obscured references in scriptural silences.

In the first of his Miscellany Tracts, for instance, Browne discusses how certain plants "have their express Names in Scripture" while "others are implied

26. Augustine, The Literal Meaning of Genesis 6.10-6.14, 2 vols., trans. John Hammond Taylor (New York: Newman Press, 1982), 1:189-96.

27. John Wilkins, A discourse on a new planet 1.2 (London, 1640), 32-36. 
[...] which are not explicitly mention'd" and, earlier in the same tract, he glosses several verses concerning an almond tree (Jer. 1.11-12; Eccles. 12.5) as "more Emphatical" than they are usually interpreted, a comment that illustrates the degree to which Browne's natural-philosophical investigations rest upon a "reciprocal hermeneutics" of the scriptures attentive to ellipses, rhetorical foreshortenings, and what Browne, in the opening book of Pseudodoxia, calls the "deuteroscopy, and second intention of the words." 28

In the 1630s and 1640s, English theologians and biblical commentators working across confessional lines venture to fill in scriptural silences and to explain the reasons for certain omissions-interpretive habits that become both more pressing and more complicated in the wake of the New Science. Debates over ecclesiological practices such as infant baptism and observance of the Sabbath, hinging as they did on the question of whether the Church of England should embrace or reject doctrines and practices in the absence of explicit and clear scriptural endorsement or prohibition, lay bare the need to refine Hooker's emphasis upon the limited and circumstantial validity of arguments based on negative authority. In his commentary on the Old Testament, Andrew Willet tackles the problem of Melchizedek's unspecified parentage in chapter 14 of Genesis by distinguishing between those omissions that concern "matter of fact," for which "it is no good argument to conclude negatively out of Scripture," and those that concern crucial points of faith and doctrine, for which "the argument holdeth well, there is no such thing taught in Scripture, therefore wee are not to beleeve it." ${ }^{29}$ Like Wilkins, Willet strives to maintain a strict distinction between matters of fact and matters of faith, and yet the example of Melchizedek's parents proves just how hazy the distinction might be between things irrelevant to salvation and things essential to it, as well as between places where the Bible appears to "speak superficially" and places where it aims (in Ross's words) to be "exact." At Hebrews 7.3, Paul interprets the not-naming of Melchizedek's father and mother as an implicit sign that "his years have no beginning, his life no end," glossing the omission in Genesis by

28. $M T$ 1.46; 1.24, in $K 3: 44,18 ; P E 1.3 ; R R$ 1:16; on Browne's practice of a "reciprocal hermeneutics in which natural philosophy can explicate the accommodated meaning of the biblical text," see Killeen, Biblical Scholarship, 24.

29. Andrew Willet, Hexapla in Genesin \& Exodum: that is, A sixfold commentary upon the tvvo first bookes of Moses (London, 1633), 139. Willet also addresses the silence of scripture concerning the creation of the angels (14) and whether Noah lived abstinently during the Flood (70). 
turning the parentless Melchizedek into a precursor of Christ and a figure of eternity, in the process fleshing out a seemingly inconsequential oversight by overlaying upon it a typological allegory.

This habit of using scripture to interpret scripture, and especially of "filling in" omissions or obscure passages by collating them with verses of greater clarity or assertiveness, is central to John Calvin's work as a biblical commentator. Calvin's assumptions of scriptural unity, self-sufficiency, and perspicuity encouraged him to seize every opportunity to interpret the most cryptic of scriptural verses according to the principle that the Bible exhibits a "certayne kinde of silence or concealing, when we wil have more understood, then we expresse by words." ${ }^{30}$ To grasp these silences, and to discern those places where Christ means more than he speaks, demands shunning a quantitative sort of literalness in favour of what Browne calls "deuteroscopy," a hermeneutic practice that demands a certain charitable impulse on the part of the reader to deduce Christ's tacit yet unspoken intentions. Attacking the "Monkes [...] and such like rascalles [who] have sottishly sette downe to themselves sixe woorkes of mercy" based on their reading of Matthew 25.34-40, "because that Christ maketh mention of no more," Calvin protests that even a child "might [...] plainly see, that by the figure Synecdoche, al the workes of charity are here commended," rather than merely the six identified by name. ${ }^{31}$ For Browne, as for Calvin, scriptural silences may be designed to focus the reader's energies on points of doctrine crucial for salvation, but just as often they are represented as interpretive trials, passages that test the reader's capacity to find the spirit beneath the letter, the whole beneath the part, or the "clear evidence" of scripture's black and white truths beneath the gray scale of the text. ${ }^{32}$

30. John Calvin, A commentarie vpon the Epistle of Saint Paul to the Romanes (London, 1583), 78. Despite this claim, Calvin elsewhere echoes Ambrose: "I dare not affirme any thing, where the scripture is silent" (A Commentary upon the prophecie of Isaiah, trans. C.C. [London, 1609], 65). On Calvin's views of synecdoche and elliptica oratio in scripture, see G. R. Evans, Problems of Authority in the Reformation Debates (Cambridge: Cambridge University Press, 1992), 68.

31. John Calvin, A harmonie vpon the three Euangelists (London, 1584), 673.

32. John Calvin, Institutes of the Christian Religion 1.7, trans. Henry Beveridge, 2 vols. (Grand Rapids, MI: Eerdmans, 1957), claims that "Scripture bears on the face of it as clear evidence of its truth as white and black do of their colour" (1:69). Compare Stephen B. Dobranski's argument that omissions in English Renaissance poetic texts engage "active readers" who share the responsibility for interpreting the "audible silence" of those texts, in Readers and Authorship in Early Modern England (Cambridge: Cambridge University Press, 2005), 6, 2. 
Pseudodoxia's extensive range of subjects emulates the variety of God's creation as narrated in the opening book of Genesis, and in certain respects Browne's own "round of knowledge" retraces the encyclopedic dimensions of the book of scripture as well as the book of nature. Yet in Pseudodoxia and elsewhere, Browne is attentive both to the brevity of the scriptures and to their copiousness, observing that "The penne of Moses is briefe in the account before the flood"-in other words, the Old Testament provides such a frustrating paucity of detail about what transpired between the fall of Adam and Eve and the life of Noah that readers assume at their peril that Genesis narrates a full and complete account of this earliest and most obscure phase of biblical history (PE 1.2, RR 1:10). Despite the seeming absurdity of holding up a book as long-winded as the Old Testament as a model of brevity, a number of seventeenth-century English theologians do just that: George Salteren calls the Bible "a very short and briefe Epitome" that "in most places, and specially in the Decalogue, is to be taken Synechdochically," while Thomas Hall, grappling with the commonly acknowledged problem that Genesis never describes Adam's repentance, concludes that "if all should be written" in the Bible, "the world it selfe could not containe the books," an observation that echoes a pair of verses in John: "And there are also many other things which Jesus did, the which, if they should be written every one, I suppose that even the world itself could not contain the books that should be written." ${ }^{33}$ Both Salteren and Hall interpret this rather Borgesian image of a library vaster than the universe itself as proof that readers must suspend their judgment about things unmentioned by the scriptures, and also as evidence that scripture is (as Salteren puts it) an accommodation of a divine wisdom "passing all understanding" that shrinks God's "incomprehensible love" for us into a manageable size while still containing all that is essential to salvation. Yet Browne grasps rather differently what it might mean to regard the Bible as an "Epitome" or abridgement that excises some of the matter it might have contained. Just as the book of nature, according to Browne, incorporates greater wisdom in a "compendium" than in a "divided piece and endlesse volume," so too the scriptures, according to Religio Medici, contain "more Rhetorick in [...] one sentence, than in a Library of Sermons, and indeed if those Sentences were understood by the Reader, 
with the same Emphasis as they are delivered by the Author, we needed not those Volumes of instructions, but might bee honest by an Epitome" (RM 1.15; 2.13; Endicott 21; 88). The better the reader, the smaller the volume of scripture necessary to instruct in the elements of faith, an attitude that transforms biblical brevity from a matter of shrinkage (or accommodation) into a matter of intensification, or what John Donne, in his First Anniversary (1612), calls "close-weaving." ${ }^{34}$

Browne's distinctive ideas about scriptural brevity and silence were shaped by Calvin, but also by developments in seventeenth-century Calvinism. One work in particular suggests a close affinity with Pseudodoxia: Jean D'Espagne's 1639 Les erreurs populaires es poincts generaux qui concernent l'intelligence de la religion (Popular errors and general points that concern the understanding of religion), likely a key source for Browne's own ways of thinking about scriptural silence. D'Espagne, who was minister of the French Protestant church in London from the mid-1630s until his death in 1659, observes that the Bible "conceals certain things, for in many places it speaketh even by silence, and its silence is significative" ("Car en plusieurs endroits elle parle mesme en se taisant, \& son silence est significatif"). ${ }^{35}$ Citing the example of Melchizedek's absent genealogy, birth, and death, a touchstone for many contemporary discussions of the problem, D'Espagne claims that the "very silence of Scripture is mysterious" and that this phenomenon is pervasive throughout the Old and New Testaments, though "our eye cannot see them all." Yet in the previous chapter, D'Espagne claims that when the scriptures appear dark or unclear ("tenebreuse") to certain readers, it is because readers are "looking for what is not there" ("c'est qu'ils cherchent qui n'y est pas"). ${ }^{36}$ How, then, given these contradictory guidelines, does one distinguish between "significative" silences and insignificant ones? In a 1641 treatise on the Sabbath, Hamon L'Estrange, who later produced a lengthy and erudite commentary on Pseudodoxia, tackles a similar problem as he attempts to dismantle the argument that "The Scripture mentioneth it not, Ergò It was not":

34. John Donne, The first anniversarie. An anatomie of the world (London, 1612), 15.

35. Jean D’Espagne, Les erreurs populaires ès poincts généraux qui concernent l'intelligence de la religion 4.3 (The Hague, 1639, rpt. in 1674 Oeuvres), translated as Popular Errors 4.3 (London, 1648), 190-91.

36. D’Espagne, Erreurs Populaires 4.1, 113; Popular Errors 4.3, 128. 
He that in so compendious a story as this of Moses looketh for a full relation of every small circumstance, is like to lose his longing, and may as wisely seek Pauls steeple in Hondius his map of the world. Abbridgements of stories are nets of a larger mesh which only inclose great fishes, $\tau \alpha$ $\alpha \chi \iota \lambda_{o \gamma \alpha}$, things worth mentioning; smaller fry, things of less consequence, escape them. ${ }^{37}$

L'Estrange resorts to an axiological approach likewise employed by Browne as he labours to distinguish between what the scriptures value and what they deem Parergies, or irrelevancies; what they treat with exactness and what with hazy approximation. Elsewhere in Pseudodoxia, Browne presses this distinction to slightly different effect as he explores another aspect of the larger question of how and where the Bible strives for chronological or historical precision, and where it might prove anachronistic or inexact, a problem that occupied a number of mid seventeenth-century theologians and philosophers including Isaac La Peyrère, Samuel Bochart, and Thomas Hobbes. ${ }^{38}$ In a series of chapters devoted to biblical chronology, Browne pushes back forcefully against the obsessively quantitative habits of contemporary millenarian thinkers, resisting the urge to measure out each day, or each biblical personage's birthdate and age, with mathematical precision: such calculations, according to Browne, remain "controvertible" until the "Arithmeticke of the last day determine" (PE 6.6; $R R$ $1: 483)$. Browne's doubts about the possibility of computing the precise date of the Last Judgment, or of determining whether Enoch was indeed the shortestlived of the Patriarchs, are exacerbated by his recognition, likewise noted by Marin Mersenne, that the Bible practises the common but mathematically imprecise habit of rounding off, especially with "articulate numbers," or multiples of ten. As a consequence, the "three days and three nights" during which Jonas and Christ remain, respectively, in the whale and the grave "must be taken Synechdochically, or by understanding a part for an whole day" according to Browne, much as scholars call the Septuagint the "translation of Seventy" even though the "precise number [of translators] was seventy two"

37. Hamon L'Estrange, God's Sabbath before, under the law and under the Gospel briefly vindicated from novell and heterodox assertions (London, 1641), 2; 6-7.

38. On seventeenth-century debates over the precision, or lack thereof, of biblical dates, places, and other historical details, see the chapter titled "Hobbes, Ezra, and the Bible: The History of a Subversive Idea," in Noel Malcolm's Aspects of Hobbes (Oxford: Oxford University Press, 2002), 383-431. 
(PE 6.1; RR 1:449-50). This argument renders the many numbers contained in the Bible mathematically limited in their interpretive value, a stand that in turn disables the kind of meticulous calculation of biblical chronology practised by Browne's contemporaries such as Joseph Mede and James Ussher. ${ }^{39}$

Scriptural inexactness, for Browne, does not merely strive to pass over what is inconsequential for salvation but also to conceal, as mysterious, what ought not to be laid bare. Browne's recurrent assessment of the scriptures as "emphatic" - as implying more than they plainly state-at times highlights the apophatic dimensions of the Bible, for instance the "negative description" that Saint John provides of the pavement of the palace of the New Jerusalem, "Which neither eye hath seene, nor eare hath heard," because John was, according to Browne's reckoning, "translated out of himself to behold it, but being returned into himselfe could not expresse it" ( $R M 1.49 ; E 57)$. While Browne understands John's negative description as a function of the necessary accommodation of divine truths to an intellect "too weake to expresse the materiall Heaven" as it actually appears, the tropes of praetermission (praeterito) and reticentia that Browne attends to in Pseudodoxia and Miscellany Tracts are not, for the most part, instances of the kind of self-unsaying or apophatic discourse typical of negative theology. Rather, the not-naming of Melchizedek's parents, the omission of Jesus's childhood, and the approximate enumeration of biblical ages and dates constitute a different sort of negativity or absence, one attributable not to the inherent indescribability or inexpressibility of a given scene or figure but rather to other causes both theological and semiotic.

Browne's understanding of scriptural silence is rooted less in conventional ideas of the apophatic than in his own, peculiar conception of the hieroglyphic, an alphabet to him at once mystical and common, silent and crystal clear. Recounting the development of the "Hieroglyphical pictures of the Egyptians" in book 5 of Pseudodoxia, Browne explains that after the collapse of the Tower of Babel, when "words were confounded," the Egyptians found the "best evasion" by inventing a language through which they "discoursed in silence, and were intuitively understood from the theory of their Expresses" ( $P E$ 5.20, $R R$ 1:419). Like the "mute and silent discourses" of the Egyptians, scriptural omissions function to "expresse complexed significations" without giving them voice, a manner of speaking that does not so much reflect the imperfection 
of human language in contradistinction to the perfection of God but rather betokens a confident assurance in the power of language to convey meaning even through silence, creating a kind of mesure sur rien, the soundless interval at the beginning of a piece of music that determines the tempo and so forms an essential part of the piece despite making no sound. In his 1636 Clavis Mystica, Browne's contemporary Daniel Featley appeals to the foreshortening techniques of the painter as well as the "unexpected stops and rests" of the musician in order to explain how "strains of Rhetorike" may likewise "affect the judicious eare [...] express[ing] more by expressing lesse [...] making a kinde of Aposiopesis and harmonicall Ellipsis." ${ }^{40}$

In Religio Medici, Browne invokes the hieroglyphic as a way of offering a limited endorsement of the Platonic-Pythagorean doctrine of the Music of the Spheres, which might "give no sound unto the eare" and yet "strike a note full of harmony" unto the "understanding" (RM 2.9; E 80). This silent music, which Browne terms a "Hieroglyphicall and shadowed lesson of the whole world," provides instruction in theological accommodation but also in the nature of history, one that shapes his antiquarian sensibilities, his deeply philological approach to the texts of the Old Testament, and in particular his profound appreciation of the material precarity and transience of ancient documents and objects. History, for Browne, is fundamentally elliptical, punctuated by silences and gaps. Throughout the chapters on biblical chronology in book 6 of Pseudodoxia, for instance, he dwells on the problem that "we have little or no assistance" from the "fragments and broken records" of the earliest eras of history (PE 6.6; RR 1:471). Browne's repeated lament that "we have no ancient story" for much early biblical history leads him to make some rather dubious scholarly decisions-trusting, for example, in the forgeries of Annius of Viterbo that purport to be the remains of Berosus's lost account of Babylonian history-but it also nurtures in him a poignant recognition that to study history is to speak for what has been muted, whether because the "Supinity of elder dayes" has left the past "in silence" or because "time hath so martyred the Records," the twin diagnoses that preface his discussion of ancient urns in

40. Daniel Featley, Clavis mystica a key opening divers difficult and mysterious texts of Holy Scripture (London, 1636), 80-81. 
Hydriotaphia-objects that "lay, almost in silence among us" until Browne's text allows them to speak once again. ${ }^{41}$

Let us return to Browne's argument that the not-naming of something in a book does not imply its non-existence. In one of several discussions of this problem in Pseudodoxia, Browne cites an instance of "negative authority" mentioned by Josephus in order to explore the evidentiary validity of arguments from silence: "neither in Herodotus or Thucydides," Browne writes, "do we finde any mention of Rome," and yet it certainly does not follow that Rome did not exist (PE 6.6; RR 1:482). In book 1 of Pseudodoxia, Browne cites the same example to demonstrate a logical fallacy he terms "illation in the negative," arguing that it is "of no consequence that Herodotus writing nothing of Rome, there was therefore no such City in his time," and citing as a comparable example the peril of concluding that "because Dioscorides hath made no mention of Unicorns horn, there is therefore no such thing in Nature" (PE 1.7; RR 1:43). Browne's aim in citing both instances of textual silence is to testify to a habitual error of human reason, namely our tendency to "conclud[e] not only affirmatively but also negatively. [...] Although it be confessed, the affirmative hath the prerogrative illation, and Barbara engrosseth the powerful demonstration" (PE 1.7; $R R 1: 43)$.

What transpires in this passage is rather extraordinary. Browne shifts a rhetorical and hermeneutic problem - the question of what, if any, conclusion may be drawn from textual omissions or lacunae-to a problem of Aristotelian logic. If "illation" or assertion in the negative is not as persuasive as are propositions in the affirmative, Browne suggests, it is because syllogisms that begin with a universal or particular negative are not as logically sound as Barbara, a first-figure syllogism (AAA-1) in which two universal affirmatives confirm a third universal affirmative. By accommodating a textual problem to a logical one, Browne recasts the hermeneutic problem of negative authority in syllogistic terms, and the link suggests that arguments from silence commit fallacies similar to those perpetrated by second- and third-figure syllogismssyllogisms whose first premise is a universal or particular negative and which were widely held during the Renaissance to be fallacious, or even if logically

41. Thomas Browne's dedication to Hydriotaphia, also known as Urn-buriall, from The Prose of Sir Thomas Browne, ed. Norman Endicott (New York: Anchor Books, 1967); 246. 
sound, like Celarent, more remote or "weaker" because hybrid. According to Thomas Blundeville, the "particular is alwayes accounted weaker then the universall, and the Negative weaker than the Affirmative" in syllogisms, an observation that goes a long way towards explaining Francis Bacon's distaste for Aristotelian logic. ${ }^{42}$ Late sixteenth- and seventeenth-century logic textbooks, however, assert that "in every Syllogisme it behoveth either one or both of the premises to be affirmative" and that out of "two pure Negative Propositions nothing can bee orderly concluded," a hypothesis that Blundeville proves with the following example: "No man is a tree, but no Peare tree is a man: Ergo, No Peare tree is a tree: which Syllogisme cannot be good, for the premisses are both true, and the conclusion is false." 43

Browne was by no means the only Renaissance writer to appreciate that the problem of negative authority might usefully be considered from the vantage of Aristotelian logic. During the Admonition controversy, John Whitgift attacked Thomas Cartwright's reliance upon negative arguments from the scriptures by accusing him of ignorance of Aristotle's Prior Analytics, or Priorums, since Cartwright failed to understand that "you cannot conclude affirmatively in the second figure." ${ }^{44}$ In book 1, chapter 4 of Pseudodoxia, Browne tackles this kind of logical fallacy in particular, arguing that the "most usuall inconsequencies are from particulars, from negatives, and from affirmative conclusions in the second figure," for example the kind of false inference drawn from syllogisms that follow this pattern:

No fish are dogs,

No dogs can fly,

Therefore, all fish can fly. (PE 1.4; $R R$ 1:27)

Browne's invocation of Barbara in a discussion of negative authority illustrates that the Aristotelian logic he studied with Thomas Lushington at Broadgate's Hall, Oxford is not a closed system but rather a method for shaping the interpretation of scriptural texts, and indeed all texts, particularly in passages

42. Thomas Blundeville, Art of Logick 5.5 (London, 1617), 142.

43. Blundeville, 142 .

44. Peter Mack, Elizabethan Rhetoric: Theory and Practice (Cambridge: Cambridge University Press, 2002), 267-68. 
where the reader must proceed deductively, or from negatives to affirmatives. ${ }^{45}$ While "every Art hath its own circle" according to Browne, such that "divinity" need not adhere to the "strict and definitive expressions" of philosophy, the causal structures of syllogistic logic might still help to establish valid interpretations of scriptural texts, especially in cases where the Bible "omitteth the exact account of things" (PE 1.9; RR 1:54).

In Pseudodoxia's chapter on the ostrich, Browne likewise invokes the language of Aristotelian logic to explain how false assumptions may be generated from an absence of affirmative evidence, for instance assuming the bird's capacity to digest iron based on its evident tendency to consume stones, a "fallacy of the consequent," as Browne terms it, "concluding a position of the consequent, from the position of the antecedent" (PE 3.22; RR 1:252-53). Interpreting the underlying meaning of a text might appear to be a very different intellectual activity from drawing a logical conclusion in a syllogism, yet early modern treatises on logic frame their discussions of which syllogisms are and are not valid in terms strikingly similar to those employed by theologians debating the negative authority of the scriptures, especially when addressing composite or truncated syllogisms (enthymemes), or those that, like petitio principii arguments, have unstated or missing premises and thus "silently contai[n] the antecedent part of the question in the assumption, though it be not exprest." 46 The silent or missing portion of a syllogism, like tacit passages in a text, reveals unspoken truths synecdochally; conversely, synecdoche is not simply a rhetorical figure but also, at least as Quintilian defines it, a mechanism for authenticating logically valid conclusions that can "mak[e] us realize many things from one, the whole from a part, the genus from a species, things which follow from things which have preceded" ("ex uno plura intellegamus, parte totum, specie genus, praecedentibus sequentia, vel omnia haec contra”). ${ }^{47}$

45. On Lushington and Browne, see Frank L. Huntley, "Dr. Thomas Lushington (1590-1661), Sir Thomas Browne's Oxford Tutor," Modern Philology 81:1 (1983): 14-23.

46. Alexander Richardson, The logicians school-master: or, A comment upon Ramus logick (London, 1657), 301.

47. Quintilian, Inst. Orat. 8.6.19 (LCL 126: 434). Compare George Puttenham, Arte of English Poesie 3.17 (London, 1589), 154: "the Greeks then call it Synecdoche, the Latines sub intellectio or understanding, for by part we are enforced to understand the whole, by the whole part, by many things one thing, by one, many, by a thing precedent, a thing consequent." 
This is precisely how Thomas Hobbes, an early and subtle reader of Browne's Pseudodoxia, represents the figure of synecdoche as functioning within a logical (and expressly legal) domain, arguing in his 1651 Leviathan that the will of the sovereign may be exerted through his silence, since his forbearance and "inferences" may signal consent even where the "letters themselves are silent." ${ }^{\prime 8}$ For Hobbes, inference is principally a problem of logic, classified in De Corpore as one of the "Errors which happen in Reasoning, that is, in Syllogizing." Yet while Hobbes maintains a distinction between spoken or written propositions and the ideas or assertions contained in those propositions, he also recognizes that inferences may be produced out of what is, or is not, contained in language, writing in Leviathan that "Signes by Inference, are sometimes the consequence of Words; sometimes the consequences of Silence," such that it is possible to enter into a contract without a spoken or written utterance, even as words alone may be insufficient for establishing a binding contract if uttered in a future or conditional tense. ${ }^{49}$ Whereas Browne explores the problem of scriptural silence as an opportunity for interpretive liberty, Hobbes appropriates the language of seventeenth-century debates over negative authority in order to develop a theory of political obligation that guarantees the freedom of its subjects through the idea of tacit consent and to translate questions surrounding scriptural silence into the manifestly political problem of what, exactly, constitutes a sufficient sign of tacit consent to a social or political contract when that consent may not be explicitly expressed..$^{50}$

As I annotate Pseudodoxia Epidemica for a new edition of the work, I occasionally encounter moments when my text-Browne's text-is puzzlingly silent, and I wonder how best, if at all, to provide a gloss on those omissions. It is difficult not to see Browne's sustained attention to the problem of silent authority in Pseudodoxia and other writings as an invitation to think about Pseudodoxia's own omissions-the subjects it passes over, or hints at, without addressing overtly. Like Galen before him, Browne seems to appreciate that

48. Thomas Hobbes, Leviathan 1.14; 2.21-22 (London, 1651), 66-67, 113-17.

49. Thomas Hobbes, De Corpore 5.2, in Elements of Philosophy (London, 1656), 42; Leviathan 1.14, 66-67.

50. On Hobbes's understanding of tacit consent, see Arash Abizadeh, "Sovereign Jurisdiction, Territorial Rights, and Membership," in The Oxford Handbook of Hobbes, ed. A. P. Martinich and Kinch Hoekstra (New York: Oxford University Press, 2016), 421-22. 
certain topics, especially those that touch upon contemporary debates, might best be consigned to the physician's own "Register of Hell," a stance that exacerbates the "open but inscrutable" narrative persona that a number of scholars have detected in Browne. ${ }^{51}$ If Browne's frequent habit of noting what is not explicitly present in a text may pose moral hazards by turning the implicit into the dangerously explicit, the risky consequences of this exegetical practice are likewise disclosed by the existence of many passages in Pseudodoxia that speak in a circumlocutory manner about delicate or controversial subjects, in particular the English Civil War, an event that features in Pseudodoxia only tacitly. ${ }^{52}$ Yet as Michael Wilding and Jonathan Post have argued with respect to the 1643 alterations to Religio Medici, and as Kevin Killeen has demonstrated for Pseudodoxia, Browne's apparent abstention from political controversies is itself political, and his commitments and concerns "latent but legible" to contemporary readers even when he "silently omits the existence of any controversy" in his discussion of contentious topics. ${ }^{53}$

In book 2, chapter 6 of Pseudodoxia, for example, Browne compares the Rose of Jericho, a plant that blooms at Christmastime, to the Thorn at Glassenbury (or Glastonbury), a bush that exhibits similarly "strange effects" which are "naturally taken for miracles by weaker heads" ( $P E$ 2.6.4; $R R$ 1:150). The passing reference to this native English plant-another one grows, Browne adds, at Parham Park in Suffolk, owned until 1644 by Royalist MP Sir Edward Bishopp, 2nd Baronet-is striking for what it omits, namely the

51. See Cunningham, 13; here, Cunningham cites Joan Webber, "Sir Thomas Browne: Art as Recreation," in her The Eloquent I: Style and Self in Seventeenth-Century Prose (Madison, WI: University of Wisconsin Press, 1968), 151-53.

52. Compare N. H. Keeble's argument about John Milton's silence concerning Cromwell in 1658, betokening his "disillusion" with the Protectorate; see his "Nothing Nobler than a Free Commonwealth," in The Oxford Handbook of Milton, ed. Nicholas McDowell and Nigel Smith (Oxford: Oxford University Press, 2011), 306.

53. See Michael Wilding, "Religio Medici in the English Civil War," in Approaches to Sir Thomas Browne: The Ann Arbor Tercentenary Lectures and Essays, ed. C. A. Patrides (Columbia, MO and London: University of Missouri Press, 1982),100-14; Jonathan Post, "Browne's Revision of Religio Medici," Studies in English Literature 25 (1985), 145-63; Kathryn Murphy, "The Contexts of Thomas Browne," in 'A Man Very Well Studyed': New Contexts for Thomas Browne, ed. Murphy and Richard Todd (Leiden and Boston: Brill, 2008), 5; Kevin Killeen, "The Politics of Painting: Pseudodoxia Epidemica and Iconoclasm," in Sir Thomas Browne: The World Proposed, ed. Reid Barbour and Claire Preston (Oxford: Oxford University Press, 2008), 190. 
oft-repeated (and as oft-maligned) legend that the thorn sprang up where Joseph of Arimathea planted his staff at Glastonbury Abbey, the legendary birthplace of British Christianity. In the early seventeenth century, Bishop James Montague initiated a tradition of sending a budding branch of the thorn to Queen Anne every Christmas; according to various accounts, the tree was cut down as a superstitious relic by Cromwell's troops, or alternately by Roundheads, during the Civil War. But according to Dean Christopher Wren's long marginal annotation on Browne's text, the tree "now sprowtes up againe, and may renew his oakye age againe," a heavy-handed symbol of the anticipated resurrection of the Stuart monarchy for Wren, as for other contemporaries such as Godfrey Goodman, who interprets the felling of the tree in the 1640s as a symbol of the "Persecution" of true Christians. ${ }^{54}$ The plant's miraculous powers, or lack thereof, are discussed with varying degrees of wonder and skepticism by seventeenth-century English writers including Camden, Selden, Drayton, Fuller, and Heylyn, and indeed accounts of the thorn of Glastonbury are so pervasive in the first half of the seventeenth century that early readers of Pseudodoxia would very likely grasp the topical political and religious significance of the thorn in spite of Browne's failure to spell it out. The omission may signal Browne's doubts about the plant's marvelous characteristics, but it may also reflect his sense that "silence commendeth history" when it comes to the Civil War, an event that Pseudodoxia passes over as if it were one of Galen's unmentioned poisons.

One paragraph later in the same chapter (2.6.5), Browne mentions another plant, Ferrum Equinum (Moonwort or Horseshoe Vetch), likewise associated with a Civil War era legend. The plant was widely held to possess magnetic powers that could pull the iron shoes off horses, as was claimed to have occurred to the horses ridden by the Earl of Essex's troops during the 1642 battle at White Down in Devonshire, according to Nicholas Culpeper, among others. ${ }^{55}$ Browne nowhere relates this legend, not even to debunk it as a popular

54. Bodleian O.2.26 Art. Seld., Browne, Pseudodoxia Epidemica (London, 1646), 100, with annotations by Dean Christopher Wren; Godfrey Goodman, The two great mysteries of Christian Religion (London, 1653), 4 .

55. Nicholas Culpeper, The English physitian (London, 1652), 84: "I have heard Commanders say, That on White Down in Devon. neer Tiverton, there was found thirty Hors shoos, pulled off from the feet of the Earl of Essex his Horses being there drawn up in a Body, many of them being but newly shod, and no reason known, which caused much admiration." 
error, yet the recent battle, one of the last decisive victories for Royalist forces before the tides turned at Newbury and Marston Moor the following year, haunts the passage tacitly, inviting the reader to consider the topical, political relevance of a botanical legend without ever explicitly making mention of the myth itself.

A final pair of examples should suffice to illustrate Browne's habit of alluding tacitly to current events and controversies in such a manner as to convey his reluctance to introduce explicitly into Pseudodoxia topics related to the heated and divisive conflicts of the era in which it was composed. In two chapters devoted, respectively, to the arguments that right and left, and East and West, are "respective and mutable" rather than absolute and fixed distinctions, Browne insists upon the arbitrariness of these spatial and locomotive categories without acknowledging how such an argument might contribute to contemporary ecclesiological debates over the placement of altars and the direction of prayer, questions which assumed particular urgency on the eve of the Civil War (PE 6.7; RR 1:484). Although Browne does explore the faulty geographical principles behind the custom of "Jews and Mahometans" who pray towards the East, a ceremony he asserts "is only Topicall" or symbolic inasmuch as some Jews and Muslims live to the east of Jerusalem and Mecca, rather than to their west, he nowhere mentions any of the more local applications of his theory. In Browne's own adopted hometown of Norwich, for instance, Bishop Matthew Wren (Bishop of Norwich and then of Ely, 1635-41) was impeached for "standing at the West side of the [altar] Table with his face to the East" to administer the Eucharist, a punishment that might have been revoked in light of Browne's claim that East and West, and right and left, possess no "constant roote in nature" (PE 4.5; RR 1:303).

Given the tenor and purpose of Pseudodoxia, it is not surprising to find Browne steering clear of discussions of current events, especially those connected with the Civil War, for the work appeals to the collaborative investigation of natural facts and employs a skepticism that grows out of Browne's appreciation of the perils of dogmatism and factionalism. This epistemological position is aimed at combatting sectarian conflict both within the text's principal fields of inquiry and outside of them. Knowledge, for Browne, needs to be defended and advanced not by those who "conceive themselves infallible, or set downe their dictates as verities irrefragable" but rather by those who proceed "with Judgement and Ingenuity, establishing their assertion[s], not onely with great 
solidity, but submitting them also unto the correction of future discovery" ( $P E$ 1.6; $R R$ 1:32). 